\title{
The Implementation of Restorative Justice Approaches in Completion of Minor Offences
}

\author{
Nurfadillah Ridwan*, A. M. Syukri Akub, ${ }^{* *}$ Wiwie Heryani*** \\ *Graduate Student, Faculty of Law, Hasanuddin University, Indonesia \\ ${ }^{* *}$ Professor, Faculty of Law, Hasanuddin University, Indonesia \\ ${ }^{* * *}$ Associate Professor, Faculty of Law, Hasanuddin University, Indonesia
}

\begin{abstract}
This study aims to analyze the forms of implementing restorative justice carried out by law enforcement officials in the completion of minor offenses, as well as the obstacles experienced by law enforcement officials in implementing the restorative justice approach to the completion of minor offences. This type of research is a prescriptive reasearch, data sources consist of primary data and secondary data. Primary data obtained through interviews with related parties and secondary data obtained through documents relating to the restorative justice approach in the completion of minor offenses. The results showed that in the four indicators used by law enforcers in implementing the restorative justice approach in completion of minor offenses, namely mediating victims, perpetrators of compensation, restitution and community services. The indicator that is often used by the Wajo District police is the mediation of the victims, because in this way it facilitates the implementation of the restorative justice approach in completion of minor offenses. The obstacles experienced by law enforcement officers in implementing the restorative justice approach to the completion of minor offenses namely in terms of regulation using the Circular of head Indonesian National Police Number: SE/8/VII/2018 regarding the application of restorative justice in the completion of minor offences cases, readiness of facilities/inadequate infrastructure and differences in perceptions between work units to one another so that it inhibits the implementation of the restorative justice approach in completion of minor offences.
\end{abstract}

Keywords: implementation, minor offences, restorative justice.

DOI: $10.7176 / \mathrm{IAGS} / 77-06$

Publication date: November $30^{\text {th }} 2019$

\section{Introduction}

The success of national development has increased community legal awareness. ${ }^{1}$ The Criminal Code (KUHP) divides offenses or criminal acts in two groups, namely crime (misdrijvenj) and Abuse (overtredingen) which are equally regulated in Book II of the Criminal Code. The search for an understanding of minor criminal offenses is increasingly difficult, which in the Criminal Code itself does not regulate it. As for Wirjono Pradjodikoro in his book 'Principles of Criminal Law in Indonesia' states that: "In the Criminal Code there are several crimes concerning property (vermogendelicten), if the losses caused do not exceed twenty-five rupiahs, they are called "minor offences" (lichte misdren) and are only called a maximum sentence of 3 months imprisonment. This minor offences is:

a. Mild theft in Article 364 of the Criminal Code

b. Minor maltreatment in Article 352 paragraph (1) of the Criminal Code

c. Minor insults in Article 315 of the Criminal Code

d. Land grabbing in Article 385 paragraph (1) of the Criminal Code. ${ }^{3}$

So far, the judiciary has been patterned with retributive justice which sees crime as a violation committed against the state. ${ }^{4}$ According to Setyo Utomo, that there are other features that stand out from

\footnotetext{
${ }^{1}$ Nilawati Adam and Maria Ana Liwa, Pelayanan Kesehatan dari Kajian Hukum dan Hak Asasi Manusia, Jurnal Ilmu Hukum "The Juris", Vol. II No. 2, December 2018, p. 103

2 Jonlar Purba, 2017, Penegakan Hukum Terhadap Tindak Pidana Bermotif Ringan Dengan Restorattive Justice, Jakarta: Jala Permata Aksara, p. 4

${ }^{3}$ Jonlar Purba, 2017, Ibid. p. 97

${ }^{4}$ Kuat Puji Prayitno, Restorative Justice untuk Peradilan di Indonesia, Perspektif Yuridis Filosofis dalam Penegakan Hukum in Concreto, Jurnal Dinamika Hukum, Vol. 12 No. 3, September 2012, p. 408
} 
restorative justice, where crime is placed as a symptom that is part of social action and not merely a violation of criminal law. ${ }^{1}$ Even in BAPAS Purwokerto from 2002-2008 the most common type of crime committed by children is theft, after that sequentially namely persecution, decency, traffic accidents, drugs and extortion. ${ }^{2}$ Principally, through the Law of the Republic of Indonesia No. 11 Year 2012, the restorative justice approach and diversification process have been put forward as efforts to resolve criminal acts committed by children, so that the application of restorative justice will offer answers to important issues in the resolution of criminal cases, namely: first, criticism of the criminal justice system that does not provide opportunities especially for victims (criminal justice system that disempowers individuals); second, eliminating conflict, especially between perpetrators and victims and the community (taking away the conflict from them); third, the fact that the feeling of powerlessness experienced as a result of a criminal offense must be overcome to achieve improvement (in order to achievereparation). ${ }^{3}$ Even Mark S. Umbreit and Marilyn Peterson Armor suggest that:

"restorative justice is viewed as complementary to the criminal justice system because it attends to issue that the traditional system neglects. Regardless of the position taken, the vision of the restorative justice is grounded in values that are resonating with an increasingly broad range of individuals and communities throughout the world, presenting many opportunities for new and wide ane widened impact". 4

One example of the resolution of minor offenses through the restorative justice approach, namely in the case of a traffic accident that occurred on Monday, December 21, 2015 around 14.00 WITA on Jalan Perintis Kemerdekaan in front of Car Wash, House No. 22. Sudiang, Biringkanaya District of Makassar, a Honda CBR motorbike No. Reg. DD 2792 QA which was driven by Dermawan Boyong (Party II) moving from north to south to Independence Road, turn right to the west to enter KH. Jabbar Asiri in side Coca-Cola factory collision with a Honda Beat No. motorcycle. Reg DD 6545 JR driven by Kaharuddin (Party I) moves from south to north on Jalan Perintis Kemerdekaan Sudiang, Biringkanaya District, Makassar. As a result of the traffic accident both motorcycle riders were injured, and both motorbikes suffered damage. The case of the traffic accident, by holding a family meeting and deliberation by taking a joint agreement as follows:

a. Party I sincerely helped the cost of repairing vehicle damage to Party II, amounting to Rp. 500,000

b. Party II willingly accepts the assistance from Party I

c. Both parties realize that the traffic accident experienced was an accident that did not occur, there was no element of intent, therefore both parties forgive each other, and will not sue to sue the court before the Court both in Criminal Law and Civil Law.

d. Both Parties declare that if the above is not true/reneged, they do not comply and are willing to be prosecuted according to the applicable Law.

In connection with traffic accidents carried out by Party II on behalf of Generous Boyong to Party I on behalf of Kaharuddin, the accident case occurred because there was no intentional element carried out, and Party II used Restorative Justice approach with the aim to recover from accident cases that occur.

Crime according to the perspective of Restorative justice, is a violation of humans and human relations. Restorative justice can be carried out through: Mediation of victims and violators; Family Group Consultation; services in the community that are of a recovery nature for both victims and perpetrators. ${ }^{5}$ The restorative justice approach is a form of the settlement process which is a way out of the problem between several parties who have experienced a traffic accident, and the Restorative Justice approach in its implementation is more easy because

\footnotetext{
${ }^{1}$ Setyo Utomo, Sistem Pemidanaan Dalam Hukum Pidana yang Berbasis Restorative Justice, Jurnal Mimbar Justitia Fakultas Hukum Universitas Suryakancana, Vol. 5, No. 1, 2011, p. 86.

${ }^{2}$ Angkasa, Saryono Hanadi dan Muhammad Budi Setyadi, Model Peradilan Restoratif dalam Sistem Peradilan Anak (Kajian Tentang Praktik Mediasi Pelaku dan Korban dalam Proses Peradilan Anak di Wilayah Hukum Balai Pemasyarakatan Purwokerto, Jurnal Dinamika Hukum, Vol. 9 No. 3 September 2009.

${ }^{3}$ Ivo Aertsen, et.al, Restorative Justice and the Active Victim: Exploring the Concept of Empowerment, Journal TEMIDA, 2011, p. 8-9

${ }^{4}$ Mark S. Umbreit and Marilyn Peterson Armour, Restorative Justice and Dialogue: Impact Opportunities, and Challanges in the Global Community, Washington University Journal of Law \& Policy, Vol. 6, No. 36, 2011, p. 82

${ }^{5}$ Hanafi Arief dan Ningrum Ambarsari, Penerapan Restorative Justice dalam Sistem Peradilan Pidana di Indonesia, Jurnal Al'Adl, Vol. X, No. 2, July 2018, p. 174
} 
the victims and perpetrators conduct deliberations in a family that is accompanied by the facilitator to the get results quickly, easily, and the absence of proceedings to the Court. Based on the explanation, the problem that will be examined in this paper is how are the forms of restorative justice implemented by law enforcement officers in completion of minor offenses? and what obstacles are experienced by law enforcement officers in implementing the restorative justice approach to the completion of minor offenses?

\section{Research Method}

This type of research used in this research is prescriptive research, ${ }^{1}$ namely research that aims to provide an overview or formulate the problem in accordance with the circumstances/facts that exist. The approach used is the statute approach ${ }^{2}$ which is an approach using legislation and regulation. Primary data were obtained through direct interaction with related parties, both through interviews and in the form of observations. Secondary data is carried out by researching the literature using various literatures to obtain a theoretical basis, in the form of a collection of legal principles, norms, legal norms, opinions of experts, doctrines, results of scientific research, other sources related to the problem to be discussed. Data collection techniques used by the author, namely interview, are data collection conducted by researchers directly by expressing questions that are relevant to the research to speakers from various related agencies. Study documentation is a data collection technique by recording documents related to the object of research. Analysis of the data used is qualitative ${ }^{3}$ and then described.

\section{Results and Discussion}

\section{A. The Application of the Restorative Justice Approach in the Completion of Minor Offences}

\section{Mediation between Victims and Perpetrators}

Criminal mediation according to Martin Wright is a process whereby victims and perpetrators of crime meet and communicate with third parties either directly or indirectly by using a third party as a liaison, making it easy for victims to express their needs and feelings and also allows perpetrators to accept and responsible for his actions. $^{4}$

Based on the results of a research interview on October 4,2019, with the head of the idik unit 3 Satreskim, Wajo District Police, Andi Irvan Fachri explained that:

"The form of settlement of cases of minor crimes committed by the Wajo District Police Department is to put forward a restorative justice approach in resolving these cases. The Wajo District Police Department did not immediately proceed with the cases of minor criminal offenses occurring in the jurisdiction of the Wajo district to the Court. In connection with the handling of these minor crimes, the Wajo district police will first provide the opportunity for the parties to settle the case in a peaceful manner. Therefore, the Wajo district police will prioritize a family approach in resolving these minor offenses cases. The handling of restorative justice in the resolution of minor offenses in the Wajo district police is one of them by mediating the victims. The victims and perpetrators were brought together by the Wajo district police in resolving criminal cases that were being experienced based on the agreement between the two parties, namely the victim and the perpetrators who wanted to carry out a mediation process. The Wajo District Police in this case act as neutral mediators in witnessing the ongoing mediation process, what will happen during the meeting and the various rules or conditions that they agree to do. In the meeting between the victims themselves, the Wajo District Police Department acted as a facilitator who guided the mediation process between the victims, the victims and the perpetrators had the opportunity to express their opinions on the crimes they had experienced. In the process of carrying out the mediation of the victims, the Wajo District Police Department has the right to approve the agreed mediation results between the victim and the perpetrators in the case of minor crimes that occurred in the jurisdiction of the Wajo District Police. The mediation results agreed by the

\footnotetext{
${ }^{1}$ Bambang Waluyo, 2008, Penelitian Hukum dalam Praktek, Jakarta: Sinar Grafika, p. 9

${ }^{2}$ Peter Mahmud Marzuki, 2005, Penelitian Hukum, Jakarta: Prenadamedia Group, p. 35

${ }^{3}$ Kadarudin, Thamrin H., Liao YM. (2018) Drug-Related Crimes and Control in Indonesia and Taiwan: Cooperation Regarding Narcotics Smuggling Prevention and Countermeasures from the Point of View of International Law. In: Uden L., Hadzima B., Ting IH. (eds) Knowledge Management in Organizations. KMO 2018. Communications in Computer and Information Science, vol 877. Springer, Cham, https://doi.org/10.1007/978-3-319-95204-8_27

${ }^{4}$ Martin Wright sebagaimana dikutip oleh Marc Groenhuijsen, 1999. Victim-Offender-Mediation: Legal and Procedural Safeguards Experiments and Legislation in Some European Jurisdictions, Leuven, p. 1
} 
parties (both victims and perpetrators) in the resolution of the minor criminal offenses will be kept by the Wajo district police as evidence that the completion of the minor criminal offense by restorative justice by mediating the victims in the Wajo District Police".

\section{Compensation Fund}

Based on the results of a research interview on October 4, 2019, with the head of the idik unit 3 Santreskim, Wajo District Police, Andi Irvan Fachri explained that:

"The restorative justice approach in resolving minor criminal offenses used by the Wajo District Police is that the perpetrators or suspects are asked to return or provide compensation in accordance with the agreement between the parties, both victims and perpetrators regarding the losses suffered by the victims. After the suspect compensates the loss suffered by the victim, the suspect is then asked to make a statement which essentially states that the perpetrator will not repeat his actions. The statement was made by the perpetrator in front of the victim and the Wajo district police. When the statement letter has been completed, then the letter is handed over to the Wajo District Police Department to be stored with the hope that the suspect deterrent and will not repeat his actions again".2

\section{Restitution}

Restitution is a form of material legal protection. Based on the results of a research interview on October 4, 2019, with the head of the idik unit 3 Satreskim, Wajo District Police, Andi Irvan Fachri explained that:

"The issue of restitution to victims of minor offenses in the context of the relationship between the offender and the victim is an embodiment of the intended resocialization and it is hoped that a sense of social responsibility is embedded in the offender so that the value of restitution in this case lies not only in the efficacy of helping the victim, but serves as a tool to sensitize the perpetrators of crimes for their actions to the victim". 3

Restorative justice includes awareness of acts, apologies, recovery of victims and even compensation if necessary. This is not found in the paradigm values of restitution justice. Restorative justice values give equal attention to victims and perpetrators because the authority to determine the sense of justice is in the hands of the parties, the State functions as a facilitator.

Restorative justice can also reduce the impact of stigmatization for perpetrators, can be done in line with traditional mechanisms that are still maintained, prioritizing problem solving and at the same time finding the roots of conflict, restorative justice also pays attention to victims' losses and needs, encourages perpetrators to look deeper into the causes and consequences of their actions, realize it and take responsibility for the loss. In addition, restorative justice can also be adapted to local legal traditions, principles, and philosophies and national legal systems by placing the role of the community in an important place, not only to overcome problems that occur, but also to prevent the recurrence of criminal acts in the future. ${ }^{4}$

\section{Community Services}

Based on the results of a research interview on October 4, 2019, with the head of the idik unit 3 Satreskim, Wajo District Police, Andi Irvan Fachri explained that:

"If the restorative justice approach has been carried out, and between the parties there is no common ground so that no agreement is reached for peace or the victim still wants to resolve the case through

\footnotetext{
${ }^{1}$ Interview with Andi Irvan Fachri, Head of the Wajo District Police, Idik 3 Unit, On Friday 4 October 2019 at 09.00 WITA at the Head of the Idik Unit 3 Unit of the Wajo District Police Station.

${ }^{2}$ Interview with Andi Irvan Fachri, Head of the Wajo District Police, Idik 3 Unit, On Friday 4 October 2019 at 09.00 WITA at the Head of the Idik Unit 3 Unit of the Wajo District Police Station.

${ }^{3}$ Ibid.

${ }^{4}$ A. M. Syukri Akub and Sutiawati, 2012, Keadilan Restoratif (Restorative Justice) Perkembangan, Program Serta Prakteknya di Indonesia dan Beberapa Negara, Yogyakarta, Litera, p. 29-30.
} 
legal channels, the Wajo District Police will continue to proceed with these minor criminal cases to the level the trial by submitting a letter to conduct a trial of the minor offences". ${ }^{1}$

\section{B. Obstacles to the Implementation of the Restorative Justice Approach Against the Completion of Minor Offences}

Only at a certain level the sanctions are no longer balanced, so it needs tougher and heavier sanctions that are accompanied by criminal sanctions. ${ }^{2}$ The Due Process Model is one model that supports the criminal justice system because it separates the authority of various bodies in the criminal justice system. ${ }^{3}$ Restorative Justice has now become a trendy and popular term, especially among academics, law enforcement and law practitioners as a paradigm or approach to criminalization in handling crime or crime, both committed by children and adults. ${ }^{4}$ The obstacles experienced by law enforcement officers in implementing the restorative justice approach to the completion of minor offenses are as follows:

1. Regulations

Based on the results of a research interview on October 4, 2019, with the head of the idik unit 3 Satreskim Wajo District Police, Andi Irvan Fachri explained that:

"Polri in carrying out police duties which include police activities and police operations are given discretionary power. Discretionary authority is a legal authority in which the police have the right to continue or not proceed with a case. Based on this authority the police can also transfer to a case so that the perpetrators do not have to face formal criminal court settlement". 5

Based on the results of a research interview on October 4, 2019, with the head of the idik unit 3 Satreskim Wajo District Police, Andi Irvan Fachri explained that:

"The legal basis used by the police in implementing the restorative justice approach in resolving minor criminal offenses is the Circular of the Head National Police of the Republic of Indonesia Number: $\mathrm{SE} / 8 / \mathrm{VII} / 2018$ regarding the Implementation of Restorative Justice in completion of minor criminal offences". 6

\section{Facility/Infrastructure Readiness}

Facility/infrastructure readiness has a very important role in implementing the restorative justice approach in resolving minor offenses. Based on the results of a research interview on October 4, 2019, with the head of the idik unit 3 Satreskim Wajo District Police, Andi Irvan Fachri explained that:

The obstacles faced by investigators in implementing the restorative justice approach in handling minor offenses in terms of facilities/infrastructure, namely:

1. Regarding investigators' competence in the field of legal knowledge, laws and regulations, the criminal justice system and the technical and tactical skills of investigation are still not optimal.

2. Regarding the budget, that the investigation budget is accounted for in cases that have been submitted to the public prosecutor/P-21, so there is limited space in the settlement of the case that can be resolved at the investigation level.

\footnotetext{
${ }^{1}$ Interview with Andi Irvan Fachri, Head of the Wajo District Police, Idik 3 Unit, On Friday 4 October 2019 at 09.00 WITA at the Head of the Idik Unit 3 Unit of the Wajo District Police Station.

${ }^{2}$ S.R. Sianturi, 1986, Asas-Asas Hukum Pidana dan Penerapannya, Jakarta: Alumni Ahaem Petehaem, p. 25; See also Andi Sofyan and Nur Azisa, 2016, Hukum Pidana, Makassar: Pustaka Pena Press, p. 7

${ }^{3}$ M. Said Karim, 2019, Ganti Kerugian Terhadap Korban penangkapan yang Tidak Sah dalam Proses Peradilan Pidana, Makassar: Pustaka Pena Press, p. 68

${ }^{4}$ Ulang Mangun Sosiawan, Perspektif Restorative Justice Sebagai Wujud Perlindungan Anak yang Berhadapan dengan Hukum, Jurnal Penelitian Hukum De Jure, Vol. 16 No. 4, December 2016, p. 425

${ }^{5}$ Interview with Andi Irvan Fachri, Head of the Wajo District Police, Idik 3 Unit, On Friday 4 October 2019 at 09.00 WITA at the Head of the Idik Unit 3 Unit of the Wajo District Police Station.

${ }^{6}$ Ibid.
} 
3. There is no standard operating procedure (SOP) that can be used as a guide and legal umbrella for investigators to resolve cases outside the court or by conducting restorative justice in accordance with the interests of parties who are litigating and seeking justice.

4. The synergy of cooperation between law enforcement agencies is not yet a sub-system of the Indonesian criminal justice system. ${ }^{1}$

\section{Human Resources}

\subsection{Police}

Based on the results of a research interview on October 4, 2019, with the head of idik unit 3 Satreskim Wajo District Police, Andi Irvan Fachri explained that: There has not been synchronization between work units, for example between criminal functions, or other supporting functions to resolve community problems that arise by prioritizing the principle of restorative justice.

\subsection{Judge}

Based on the results of a research interview on October 8, 2019, with Sengkang District Court Judge, Mustamin explained that: There has not been a special synchronization between judges and one another in the application of the restorative justice approach in the resolution of minor criminal offenses. Thus we need a rule governing the implementation of the restorative justice approach in the resolution of minor criminal offenses. So that the judge can implement the restorative justice approach in resolving minor offenses. ${ }^{2}$

\section{Conclusion}

In the four indicators used by law enforcers in implementing the restorative justice approach in completion of minor offenses, namely mediating victims, perpetrators, giving compensation, restitution and community services. An indicator often used by the Wajo District Police Department is victim-perpetrator mediation. Because in this way it facilitates the implementation of the restorative justice approach in completion minor offenses. The obstacles experienced by law enforcement officers in implementing the restorative justice approach to the completion of minor offenses namely in terms of regulation are the Circular of the Head National Police of the Republic of Indonesia Number: SE/8/VII/2018 regarding the application of restorative justice in the completion of minor offenses, the readiness of facilities/inadequate infrastructure and human resources that have not been synchronized between work units with each other so that hampering the implementation of the restorative justice approach in the completion of minor offenses.

\section{References}

A. M. Syukri Akub and Sutiawati, 2012, Keadilan Restoratif (Restorative Justice) Perkembangan, Program Serta Prakteknya di Indonesia dan Beberapa Negara, Yogjakarta, Litera.

Andi Sofyan and Nur Azisa, 2016, Hukum Pidana, Makassar: Pustaka Pena Press.

Angkasa, Saryono Hanadi dan Muhammad Budi Setyadi, Model Peradilan Restoratif dalam Sistem Peradilan Anak (Kajian Tentang Praktik Mediasi Pelaku dan Korban dalam Proses Peradilan Anak di Wilayah Hukum Balai Pemasyarakatan Purwokerto, Jurnal Dinamika Hukum, Vol. 9 No. 3 September 2009.

Bambang Waluyo, 2008, Penelitian Hukum dalam Praktek, Jakarta: Sinar Grafika.

Hanafi Arief dan Ningrum Ambarsari, Penerapan Restorative Justice dalam Sistem Peradilan Pidana di Indonesia, Jurnal Al'Adl, Vol. X, No. 2, July 2018.

Ivo Aertsen, et.al, Restorative Justice and the Active Victim: Exploring the Concept of Empowerment, Journal TEMIDA, 2011.

\footnotetext{
${ }^{1}$ Interview with Andi Irvan Fachri, Head of the Wajo District Police, Idik 3 Unit, On Friday 4 October 2019 at 09.00 WITA at the Head of the Idik Unit 3 Unit of the Wajo District Police Station

${ }^{2}$ Interview with Mustamin, Judge of the Sengkang District Court, On Tuesday 8 October 2019 at 10.20 WITA at the Sengkang District Court Judge's room.
} 
Jonlar Purba, 2017. Penegakan Hukum Terhadap Tindak Pidana Bermotif Ringan Dengan Restorattive Justice, Jakarta: Jala Permata Aksara.

Kadarudin, Thamrin H., Liao YM. (2018) Drug-Related Crimes and Control in Indonesia and Taiwan: Cooperation Regarding Narcotics Smuggling Prevention and Countermeasures from the Point of View of International Law. In: Uden L., Hadzima B., Ting IH. (eds) Knowledge Management in Organizations. KMO 2018. Communications in Computer and Information Science, vol 877. Springer, Cham, https://doi.org/10.1007/978-3-319-95204-8_27

Kuat Puji Prayitno, Restorative Justice untuk Peradilan di Indonesia, Perspektif Yuridis Filosofis dalam Penegakan Hukum in Concreto, Jurnal Dinamika Hukum, Vol. 12 No. 3, September 2012.

M. Said Karim, 2019, Ganti Kerugian Terhadap Korban penangkapan yang Tidak Sah dalam Proses Peradilan Pidana, Makassar: Pustaka Pena Press.

Mark S. Umbreit and Marilyn Peterson Armour, Restorative Justice and Dialogue: Impact Opportunities, and Challanges in the Global Community, Washington University Journal of Law \& Policy, Vol. 6, No. 36, 2011.

Martin Wright sebagaimana dikutip oleh Marc Groenhuijsen, 1999, Victim-Offender-Mediation: Legal and Procedural Safeguards Experiments and Legislation in Some European Jurisdictions, Leuven.

Nilawati Adam and Maria Ana Liwa, Pelayanan Kesehatan dari Kajian Hukum dan Hak Asasi Manusia, Jurnal Ilmu Hukum "The Juris", Vol. II No. 2, December 2018.

Peter Mahmud Marzuki, 2005, Penelitian Hukum, Jakarta: Prenadamedia Group.

S.R. Sianturi, 1986, Asas-Asas Hukum Pidana dan Penerapannya, Jakarta: Alumni Ahaem Petehaem.

Setyo Utomo, Sistem Pemidanaan Dalam Hukum Pidana yang Berbasis Restorative Justice, Jurnal Mimbar Justitia Fakultas Hukum Universitas Suryakancana, Vol. 5, No. 1, 2011.

Ulang Mangun Sosiawan, Perspektif Restorative Justice Sebagai Wujud Perlindungan Anak yang Berhadapan dengan Hukum, Jurnal Penelitian Hukum De Jure, Vol. 16 No. 4, December 2016. 